\title{
Persepsi Masyarakat dalam Membayar Zakat di BAZNAS Kabupaten Pasaman Barat
}

\author{
M. Yarham¹, Saima Putri Siregar² \\ 1,2 Institut Agama Islam Negeri Padangsidimpuan \\ 1,2 Jalan T. Rizal Nurdin Km. 4,5 Sihitang, Padangsidimpuan \\ Email: ${ }^{1}$ myarhamlubis@gmail.com ${ }^{1}$
}

\begin{abstract}
Abstrak
Penelitian ini bertujuan untuk mengetahui persepsi masyarakat dalam membayar zakat di BAZNAS Kabupaten Pasaman Barat dimana masyarakat masih tetap membayar zakat sesuai tradisi di daerah tersebut. Jenis penelitian ini yaitu penelitian deskriptif kualitatif, dengan menggunakan pendekatan fenomenologi. Metode pengumpulan data melalui observasi, wawancara, dokumentasi. Hasil penelitian ini menunjukkan bahwa masyarakat masih banyak yang kurang tahu dan paham akan pentingnya fungsi, tujuan dan manfaat zakat dalam pembayaran atau penyaluran zakat melalui Lembaga Amil Zakat di BAZNAS Kabupaten Pasaman Barat. Sebagian besar masyarakat beranggapan jika memberi zakat langsung kepada orang yang membutuhkan lebih afdhal di banding ke BAZNAS. Kemudian, karena masyarakat masih kurang percaya dan kurang yakin akan tanggung jawab dari sebuah lembaga tersebut dalam menangani pengelolaan zakat serta kurang efektifnya keberadaan unit pengumpul zakat (UPZ) yang ada di daerah tersebut.
\end{abstract}

\section{Kata Kunci: Persepsi, Zakat, BAZNAS}

\begin{abstract}
This study aims to determine people's perceptions in paying zakat in BAZNAS, West Pasaman Regency where people still pay zakat according to the traditions in the area. This type of research is a qualitative descriptive study, using a phenomenological approach. Methods of data collection through observation, interviews, documentation. The results of this study indicate that there are still many people who do not know and understand the importance of the function, purpose and benefits of zakat in the payment or distribution of zakat through the Amil Zakat Institute in BAZNAS, West Pasaman Regency. Most people think that giving zakat directly to people in need is more affordable than BAZNAS. Then, because the community still lacks confidence and is not sure of the responsibility of an institution in handling zakat management and the ineffective existence of zakat collection units (UPZ) in the area.
\end{abstract}

Keywords: Perception, Zakat, BAZNAS 


\section{PENDAHULUAN}

Zakat merupakan sebuah ibadah yang tercakup dalam rukun Islam yang ketiga. (Ahmad Atabik, 2015). Zakat juga merupakan salah satu kewajiban bagi orang Islam berupa mendistribusikan harta benda yang dimiliki kepada orang yang berhak menerimanya sebagaimana telah ditentukan di dalam al-Qur'an dan Hadis sebagai wujud menjaga dan melaksanakan amanat dari Allah SWT. Zakat tidak hanya berfungsi hanya sekedar membantu orang lain, namun juga bisa berfungsi lebih dari itu. Pertama, sebagai wujud keimanan kepada Allah SWT dengan rasa syukur atas nikmat-Nya mampu menumbuhkan akhlak mulia dengan rasa kemanusiaan yang tinggi, mampu menghilangkan sifat kikir sekaligus mampu membersihkan harta yang dimiliki. Kedua, mampu menolong, membantu, membina para mustahik ke arah kehidupan yang lebih sejahtera. Ketiga, sebagai pilar amal bersama antara orang kaya dengan orang yang seluruh waktunya digunakan untuk berjihad di jalan Allah. Keempat, sebagai salah satu instrumen pemerataan pendapatan. (Muhammad Agus Yusrun Nafi, 2020).

Allah SWT memerintahkan zakat kepada setiap orang Islam yang telah layak berdasarkan hitungan nishab seseorang sehingga menumbuhkan nilai-nilai sosial yang memberikan banyak manfaat bagi manusia. Selain itu, keagungan Allah lainnya dari kewajiban zakat tersebut ialah hal tersirat berupa kewajiban untuk memiliki kepekaan dan kepedulian sosial kepada sesama manusia. Dengan mewajibkan zakat, secara otomatis Allah mewajibkan manusia untuk memiliki kepedulian dan kepekaan sosial. (Karebet Gunawan, 2017).

Besarnya manfaat zakat bagi masyarakat maka pemerintah Indonesia membentuk suatu lembaga yang khusus menangani masalah zakat yaitu Badan Amil Zakat, Infak dan Sedekah (BAZIS), mulai dari tingkat Nasional yang disebut Badan Amil Zakat, Infak dan Sedekah tingkat Nasional (BAZNAS) sampai tingkat daerah berupa Badan Amil Zakat, Infak dan Sedekah tingkat Daerah (BAZDA), Lembaga Amil Zakat (LAZ) dan Unit Pengumpul Zakat (UPZ).

Lembaga Amil Zakat juga didefinisikan sebagai institusi pengelolaan zakat yang sepenuhnya dibentuk atas prakarsa masyarakat dan oleh masyarakat yang bergerak di bidang da'wah, pendidikan, sosial dan kemaslahatan umat Islam. Lembaga amil zakat dikukuhkan, dibina dan dilindungi pemerintah. Sebagaimana dijelaskan dalam pasal 17 UU No. 23 tahun 2011 pembentukan LAZ untuk membantu BAZNAS dalam pengumpulan, pendistribusian dan pendayagunaan zakat.

Jadi, lembaga amil zakat adalah lembaga atau institusi atau badan yang didalamnya terdapat sekelompok orang yang disahkan pemerintah, baik dibentuk oleh pemerintah JISFIM: Journal of Islamic Social Finance Management, Volume 2, No 1 Tahun 2020 http://jurnal.iain-padangsidimpuan.ac.id/index.php/JISFIM 
maupun masyarakat, bertugas membantu pengumpulan, pendistribusian dan pendayagunaan zakat demi kemaslahatan umat.

Peraturan Badan Amil Zakat Nasional No. 2 Tahun 2016 tentang Pembentukan dan Tata Kerja Unit Pengumpul Zakat pada pasal 5 ayat 1 disebutkan bahwa BAZNAS Kabupaten/Kota membentuk UPZ BAZNAS kabupaten/kota pada institusi sebagai berikut: a. kantor instansi vertikal tingkat kabupaten/kota; b. kantor satuan kerja pemerintah daerah/ lembaga daerah kabupaten/kota; c. badan usaha milik daerah kabupaten/kota d. perusahaan swasta skala kabupaten/kota; e. pendidikan dasar atau nama lainnya; f. masjid, mushalla, langgar, surau atau nama lainnya; dan g. kecamatan atau nama lainnya. (Junaidi Abdullah, 2018)

Dari pasal di atas jelas disebutkan bahwa Lembaga Amil Zakat atau Unit Pengumpul Zakat (UPZ) dan lembaga zakat lainnya secara resmi dibentuk oleh BAZNAS. Dalam hal ini orang yang bertugas mengumpulkan zakat adalah orang yang secara khusus dipilih oleh BAZNAS untuk mengumpulkan, mengelola, dan mendistribusikan zakat dari masyarakat.

Hal yang sering dipertimbangkan di tengah masyarakat kita adalah kepada siapa zakat harus diberikan. Lebih utama disalurkan langsung oleh muzakki kepada mustahiq, atau sebaliknya melalui amil zakat. Jika disalurkan kepada mustahiq, memang ada perasaan tenang karena menyaksikan secara langsung zakatnnya tersebut telah disalurkan kepada mereka yang dianggap berhak menerimanya. Tapi terkadang penyaluran langsung yang dilakukan oleh muzakki tidak mengenai sasaran yang tepat. (Ahmad Thoharul Anwar, 2018). Terkadang orang sudah merasa menyalurkan zakat kepada mustahiq, padahal ternyata yang menerimanya bukan mustahiq yang sesungguhnya, seperti hanya karena kedekatan emosi maka ia memberikan zakat kepadanya. Oleh karena itu, untuk menyalurkan zakat dari muzakki untuk mustahiq diperlukan lembaga penyaluran zakat yang mempunyai tugas khusus menjadi amil zakat yakni mengalokasikan, mendayagunakan, mengatur masalah zakat, baik pengambilan maupun pendistribusiannya.

Sementara Badan Amil Zakat yang ada di Kabupaten Pasaman barat kurang dimanfaatkan oleh masyarakat muslim Kabupaten Pasaman barat terutama masyarakat Kecamatan Gunung Tuleh yang masih membayar zakat melalui panitia pengumpul zakat (amil) yang dibentuk langsung oleh masyarakat tanpa ada izin dan rekomendasi dari BAZNAS. Kemudian, ada juga sebagian masyarakat yang membayarkan langsung zakatnya kepada penerima zakat (mustahik). Berdasarkan fenomena di atas, maka penulis tertarik untuk membahas tentang bagaimana persepsi masyarakat dalam membayar zakat di BAZNAS Kabupaten Pasaman Barat.

JISFIM: Journal of Islamic Social Finance Management, Volume 2, No 1 Tahun 2021 http://jurnal.iain-padangsidimpuan.ac.id/index.php/JISFIM 


\section{KAJIAN TEORITIS}

\section{Pengertian Persepsi}

Persepsi secara umum merupakan proses perolehan, penafsiran, pemilihan dan pengaturan informasi indrawi. Persepsi berlangsung pada saat seseorang menerima stimulus dari dunia luar yang ditangkap oleh organ-organ bantunya yang kemudian masuk ke dalam otak. Persepsi merupakan proses pencarian informasi untuk dipahami yang menggunakan alat pengindraan. (Salito W. Sarwono 2002: 94).

Persepsi mengandung suatu proses dalam diri untuk mengetahui dan mengevaluasi sejauh mana kita mengetahui orang lain. Pada proses ini kepekaan dalam diri seseorang terhadap lingkungan sekitar mulai terlihat. Cara pandang akan menentukan kesan yang dihasilkan dari proses persepsi. Proses interaksi tidak dapat dilepaskan dari cara pandang atau persepsi satu individu terhadap individu yang lain, sehingga memunculkan apa yang dinamakan persepsi masyarakat. Persepsi masyarakat akan menghasilkan suatu penilaian terhadap sikap atau perilaku dan tindakan seseorang di dalam kehidupan bermasyarakat. (Rohmaul Listyana, 2015)

\section{Pengertian Zakat}

Secara bahasa zakat bisa berasal dari kata al-barakatu yang diartikan dengan keberkahan, bisa juga berasal dari kata ath-thaharatu yang memiliki arti kesucian, bisa juga berasal dari kata al-namaa yang mempunyai arti pertumbuhan dan perkembangan, dan bisa berasal dari kata ash-shalahu yang memiliki arti keberesan (Didin Hafhiduddin, 2002)

Zakat menurut pengertian syari'at adalah nama bagi sejumlah harta tertentu yang telah mencapai syarat tertentu yang diwajibkan Allah untuk dikeluarkan dan diberikan kepada orang-orang yang berhak menerimanya. Di dalam Al-Qur'an Allah SWT telah menyebutkan tentang zakat dan shalat sejumlah 82 ayat. Dari sini disimpulkan secara deduktif bahwa zakat merupakan rukun Islam terpenting setelah shalat. Zakat dan shalat dijadikan sebagai lambang keseluruhan ajaran Islam. Pelaksanaan shalat melambangkan hubungan seseorang dengan Tuhan, sedangkan pelaksanaan zakat melambangkan hubungan antar sesama manusia. Sebagaimana firman Allah SWT:

"Dan dirikanlah shalat dan tunaikanlah zakat. Dan kebaikan apapun yang kamu usahakan bagi dirimu, tentu akan mendapatkan pahala disis Allah. Sesungguhnya Allah Maha Melihat apa yang kamu kerjakan. (QS. Al-Baqarah: 10)

Dari firman Allah di atas, dapat ditarik beberapa kesimpulan, Pertama, zakat adalah predikat untuk jenis barang tertentu yang harus dikeluarkan oleh umat Islam dan dibagi-bagikan kepada golongan yang berhak menerimanya sesuai dengan ketentuan JISFIM: Journal of Islamic Social Finance Management, Volume 2, No 1 Tahun 2020 http://jurnal.iain-padangsidimpuan.ac.id/index.php/JISFIM 
syari`at. Kedua, zakat merupakan konsekuensi logis dari prinsip harta milik dalam ajaran Islam yang fundamental, yakni haqqullah (milik Allah yang dititipkan kepada manusia) dalam rangka pemerataan kekayaan. Ketiga, zakat merupakan ibadah yang tidak hanya berkaitan dengan dimensi ketuhanan saja (ghair mahdhah), tetapi juga mencangkup dimensi sosial-kemanusiaan yang kerap disebut ibadah maliyah ijtima’iyyah. (Ahmad Syafiq, 2016)

Al-Qur'an menyebutkankan bahwa pada harta yang dimiliki seseorang, didalamnya terdapat hak bagi orang lain. Hak yang utama berupa zakat, sedangkan Islam juga menganjurkan agar manusia bersedekah, berqurban, berwaqaf, berinfaq, berqurban, beraqiqah, senantiasa memuliakan tamu, menghormati tetangga, serta mentaati aturan pemerintah demi kemaslahatan umum dan ketangguhan negara. (M. Nuruddin, 2014). Dalam mazhab Syafi'i, zakat ialah sebuah ungkapan untuk keluarnya harta atau tubuh sesuai dengan cara khusus, dan diberikan kepada delapan golongan yang berhak menerima zakat. (Ahmad Atabik) Sebagaimana firman Allah SWT:

"Sesungguhnya zakat itu hanyalah untuk orang-orang fakir, orang miskin, amil zakat, yang dilunakkan hatinya (mualaf), untuk (memerdekakan) hamba sahaya, untuk (membebaskan) orang yang berutang, untukjalan Allah dan untuk orang yang sedang dalam perjalanan, sebagai kewajiban dari Allah. Allah Maha Mengetahui, Maha Bijaksana". (QS. At-Taubah: 60)

Pengertian zakat menurut Undang-Undang Nomor 23 Tahun 2011 tentang Pengelolaan Zakat Pasal 1 angka ke 2 menyatakan bahwa zakat adalah harta yang wajib dikeluarkan oleh seorang muslim atau badan usaha untuk diberikan kepada yang berhak menerimanya sesuai dengan syariat Islam. (Undang-Undang Nomor 23 Tahun 2011)

Pada dasarnya zakat memiliki beberapa fungsi, salah satu fungsi zakat adalah sebagai solusi untuk mencapai keadilan yaitu memperkecil jumlah peminta dan memperbanyak jumlah pemilik. Dengan zakat, diharapkan kemakmuran akan semakin bertambah dan mampu mengurangi kemiskinan yang dialami oleh masyarakat, selain itu kesenjangan ekonomi tidak bertambah melebar yang berakibat terjadinya kecemburuan sosial. (Fifi Nofiaturrahmah, 2015).

Zakat ditinjau dari pendekatan etnis dan pemikiran rasional ekonomis adalah sebagai kebijaksanaan ekonomi yang dapat mengangkat derajat orang-orang miskin, sehingga dampak sosial yang diharapkan dapat tercapai secara maksimal. Hal ini dapat terwujud apabila dilakukan pendistribusian kekayaan yang adil. (Fuad Riyadi, 2015).

\section{Badan Amil Zakat Nasional (BAZNAS)}

Pelaksanaan pembayaran zakat harus diawasi oleh penguasa dan dilakukan oleh JISFIM: Journal of Islamic Social Finance Management, Volume 2, No 1 Tahun 2021 http://jurnal.iain-padangsidimpuan.ac.id/index.php/JISFIM 
petugas yang rapi dan teratur, dipungut dari orang yang wajib mengeluarkan untuk diberikan kepada orang yang berhak menerima. Allah telah menyebutkan orang-orang yang bertugas dalam urusan zakat ini, baik pengumpul maupun pendistribusi zakat yaitu amil (BAZNAS). Mereka harus diberi bagian dari harta zakat, agar tanggung jawab dan kewajibannya dapat dikerjakan dengan sebaik-baiknya. (Ahmad Syafiq, 2014)

Supaya zakat bisa dimaksimalkan untuk kesejahteraan umat, maka zakat harus dikelola dengan baik dan profesional. Yang dimaksud dengan pengelolaan zakat adalah kegiatan perencanaan, pelaksanaan dan pengawasan terhadap pengumpulan dan pendistribusian serta pendayagunaan zakat (Undang-undang nomor 23 tahun 2011 tentang Pengelolaan Zakat). Pengelolaan zakat berasaskan: (a). syariat Islam; (b). amanah (pengelola zakat harus dapat dipercaya); (c). kemanfaatan (pengelolaan zakat dilakukan untuk memberikan manfaat yang sebesarbesarnya bagi mustahik); (d). keadilan (pengelolaan zakat dalam pendistribusiannya dilakukan secara adil); (e). kepastian hukum (dalam pengelolaan zakat terdapat jaminan kepastian hukum bagi mustahik dan muzaki); (f). terintegrasi (pengelolaan zakat dilaksanakan secara hierarkis dalam upaya meningkatkan pengumpulan, pendistribusian, dan pendayagunaan zakat); (g). akuntabilitas (pengelolaan zakat dapat dipertanggungjawabkan dan diakses oleh masyarakat.

Menurut hukum Islam dan peraturan yang berlaku di Indonesia tugas pengelolaan zakat dilaksanakan oleh amil. Amil zakat adalah orang yang diangkat penguasa atau wakilnya untuk mengurus zakat. Tugasnya melipu penghimpunan, pengelolaan, dan pendistribusian zakat.

Menurut Yusuf Qardhawi, dengan adanya amil ini akan memberi manfaat atau keuntungan, Pertama, Menjamin kepastian dan disiplin pembayaran zakat. Kedua, Menjaga perasaan rendah diri pada mustahiq zakat. Ketiga, Untuk mencapai efisiensi dan efektifitas serta sasaran yang tepat dalam penggunaan harta zakat menurut skala prioritas yang ada pada suatu tempat. Keempat, Memperlihatkan syi'ar Islam dalam semangat penyelenggaraan pemerintahan yang Islami (Yusuf Qardhawi, 1987).

Dalam mengelola zakat, pemerintah membentuk organisasi amil yang bernama BAZNAS. Menurut Undang Undang nomor 23 tahun 2011 tentang Pengelolaan Zakat yang dimaksud dengan Badan Amil Zakat Nasional yang selanjutnya disebut BAZNAS adalah lembaga yang melakukan pengelolaan zakat secara nasional.

BAZNAS bisa berkedudukan di pusat, provinsi maupun kabupaten/kota. BAZNAS pusat diangkat oleh presiden atas usul menteri, sedangkan BAZNAS propinsi dibentuk dan diangkat oleh menteri atas usul gubernur kemudian BAZNAS kabupaten atau kota JISFIM: Journal of Islamic Social Finance Management, Volume 2, No 1 Tahun 2020 http://jurnal.iain-padangsidimpuan.ac.id/index.php/JISFIM 
dibentuk dan diangkat oleh menteri atas saran dan usul bupati/wali kota (Peraturan Pemerintah nomor 14 tahun 2014 tentang Pelaksanaan Undang Undang nomor 23 tahun 2011 tentang Pengelolaan Zakat).

Tugas utama dari BAZNAS adalah melakukan pengelolaan zakat secara nasional. Dalam menjalankan tugas utamanya, BAZNAS mempunyai beberapa fungsi: (a). perencanaan pengumpulan, pendistribusian, dan pendayagunaan zakat; (b). pelaksanaan pengumpulan, pendistribusian, dan pendayagunaan zakat; (c). pengendalian pengumpulan, pendistribusian, dan pendayagunaan zakat; (d). pelaporan dan pertanggungjawaban pelaksanaan Pengelolaan Zakat.

(Undang-Undang No. 23 Tahun 2011 tentang Pengelolaan Zakat). Dalam menjalankan tugas dan fungsinya, BAZNAS, BAZNAS propinsi, BAZNAS kabupaten/kota bisa membentuk UPZ (Unit Pengumpul Zakat) yang mempunyai tugas mengumpulkan zakat dan menyetorkannya ke BAZNAS, BAZNAS propinsi, BAZNAS kabupaten/kota. Pengumpulan zakat oleh BAZNAZ pusat melalui UPZ dilakukan dengan cara membentuk UPZ pada: (a). lembaga Negara; (b). kementerian/lembaga pemerintah non kementerian; (c). badan usaha milik Negara; (d). perusahaan swasta nasional dan asing; (e). perwakilan Republik Indonesia di luar negeri; (f). kantor-kantor perwakilan negara asing/lembaga asing; (g). masjid negara.

Pengumpulan zakat oleh BAZNAZ propinsi melalui UPZ dilakukan dengan cara membentuk UPZ pada: (a). kantor instansi vertical; (b). kantor satuan kerja perangkat daerah/lembaga daerah provinsi; (c). badan usaha milik daerah provinsi; (d). perusahaan swasta skala provinsi; (e). perguruan tinggi; (f). masjid raya. Pengumpulan zakat oleh BAZNAZ kabupaten/kota melalui UPZ dilakukan dengan cara membentuk UPZ pada: (a). kantor satuan kerja pemerintah daerah/lembaga daerah kabupaten/kota; (b). kantor instansi vertikal tingkat kabupaten/kota; (c). badan usaha milik daerah kabupaten/kota; (d). perusahaan swasta skala kabupaten/kota; (e). masjid, mushalla, langgar, surau atau nama lainnya; (f). sekolah/madrasah dan lembaga pendidikan lain; (g). kecamatan atau nama lainnya; (h). desa/kelurahan atau nama lainnya (PP no. 14 tahun 2014 tentang Pelaksanaan UU no. 23 Tahun 2011 tentang Pengelolaan Zakat).

Sesuai dengan ketetapan Pemerintah mengenai pengelolaan zakat yaitu UU No. 23 Tahun 2011 menyebutkan Lembaga Amil Zakat (LAZ) sebagai obyek penelitian adalah suatu lembaga di lingkungan masyarakat yang dibentuk untuk membantu BAZNAS dalam pengumpulan, pendistribusian, dan pendayagunaan zakat.

Pembentukan LAZ wajib memiliki izin Menteri atau pejabat yang ditunjuk oleh JISFIM: Journal of Islamic Social Finance Management, Volume 2, No 1 Tahun 2021 http://jurnal.iain-padangsidimpuan.ac.id/index.php/JISFIM 
Menteri. Lembaga Amil Zakat (LAZ) adalah institusi pengelolaan zakat yang sepenuhnya dibentuk oleh masyarakat yang bergerak di bidang dakwah, pendidikan, sosial atau kemasyarakatan umat Islam, dikukuhkan, dibina dan dilindungi oleh pemerintah. (Nur Hisamuddin, 2014)

Sebagai institusi yang mempunyai tugas utama pengelolaan zakat, maka BAZNAS dan LAZ bisa melakukan hal-hal sebagai berikut:

Pertama, Pengumpulan zakat; Dalam pengumpulan zakat ini, muzakki bisa menghitung sendiri zakatnya. Apabila tidak bisa, maka BAZNAS atau LAZ bisa membantu untuk menghitungkan zakatnya. Zakat yang sudah dibayarkan harus dikurangkan dari penghasilan kena pajak. BAZNAS maupun LAZ harus membuat bukti setoran zakat kepada muzakki sebagai buktu untuk pengurangan pajak.

Kedua, Pendistribuan zakat; Pendistribuan harta zakat harus diserahkan kepada mustahik. Pendistribusian zakat oleh BAZNAS maupun LAZ dilakukan berdasarkan skala prioritas dengan memperhatikan prinsip pemerataan, keadilan dan kewilayahan.

Ketiga, Pendayagunaan zakat; Pendayagunaan harta zakat yang dilakukan oleh BAZNAS dan LAZ/UPZ seharusnya melalui usaha produktif untuk meningkatkan kesejahteraan para mustahik lebih-lebih fakir miskin. Sehingga dengan model produktif ini bisa mengentaskan kemiskinan. Tapi yang perlu diingat, zakat untuk usaha produktif ini dapat dilakukan apabila kebutuhan dasar fakir dan miskin sudah terpenuhi.

Keempat, Pelaporan zakat; Dalam pelaksanaan pengelolaan zakat, BAZNAS maupun LAZ/UPZ wajib melaporkan semua kegiatannya. Untuk BAZNAS kabupaten/kota wajib menyampaikan laporan pelaksanaan pengelolaan zakat kepada BAZNAS propinsi dan pemerintah daerah secara berkala. Sedangkan BAZNAS propinsi wajib menyampaikan laporan pelaksanaan pengelolaan zakat kepada BAZNAS dan pemerintah daerah secara berkala (UU No. 23 tahun 2011 tentang Pengelolaan Zakat) LAZ/UPZ wajib menyampaikan laporan pelaksanaan pengelolaan zakat, infak, sedekah, dan dana sosial keagamaan lainnya kepada BAZNAS dan pemerintah daerah setiap 6 (enam) bulan dan akhir tahun.

Perwakilan LAZ/UPZ wajib menyampaikan laporan pelaksanaan pengelolaan zakat, infak, sedekah, dan dana social keagamaan lainnya kepada LAZ/UPZ dengan menyampaikan tembusan kepada pemerintah daerah dan kepala kantor wilayah kementerian agama provinsi dan kepala kantor kementerian agama kabupaten/kota.

Laporan pelaksanaan pengelolaan zakat, infak, sedekah, dan dana sosial JISFIM: Journal of Islamic Social Finance Management, Volume 2, No 1 Tahun 2020 http://jurnal.iain-padangsidimpuan.ac.id/index.php/JISFIM 
keagamaan lainnya harus di audit syariat dan keuangan. Audit syariat dilakukan oleh kementerian yang menyelenggarakan urusan pemerintahan di bidang agama. Sedangkan audit keuangan dilakukan oleh akuntan publik.

\section{METODE PENELITIAN}

Lokasi Penelitian ini terletak di Kecamatan Gunung Tuleh Kabupaten Pasaman Barat. Dalam penelitian ini masyarakat yang diteliti ialah masyarakat muslim yang bertempat tinggal di Kecamatan Gunung Tuleh Kabupaten Pasaman Barat. Dimana daerah penelitian ditentukan secara sengaja dengan pertimbangan bahwa di daerah ini terdapat masyarakat muslim yang relatif sedikit membayar zakat melalui BAZNAS Kabupaten Pasaman Barat. Jenis penelitian ini merupakan penelitian studi lapangan dengan metode penelitian yang dilakukan yaitu penelitian deskriftif kualitatif dengan pendekatan fenomenologi, artinya suatu penelitian yang dilakukan terhadap fenomena yang terjadi pada masyarakat atau lingkungan masyarakat dengan maksud dan tujuan untuk memenuhi fakta, yang kemudian menuju kepada identifikasi dan akhirnya menuju pada penyelesaian masalah yang di amati. Penelitian ini dilaksanakan 19 Februari sampai 19 April 2021. Subjek penelitian ini adalah pengurus BAZNAS Kabupaten Pasaman Barat dan masyarakat Kecamatan Gunung Tuleh. Teknik pengumpulan data dalam penelitian ini adalah observasi, wawancara dan dokumentasi.

\section{HASIL DAN PEMBAHASAN}

\section{A. Persepsi Masyarakat Kecamatan Gunung Tuleh dalam Membayar Zakat di BAZNAS Kabupaten Pasaman Barat}

Zakat sebagai salah satu kewajiban seorang mukmin yang telah ditentukan oleh Allah SWT, tentunya mempunyai tujuan, hikmah dan faedah seperti halnya kewajiban yang lain. Diantara hikmah tersebut tercermin dari urgensinya yang dapat memperbaiki kondisi masyarakat, baik dari aspek moril maupun materil, dimana zakat dapat menyatukan anggotanya bagaikan sebuah batang tubuh, disamping itu zakat juga dapat membersihkan jiwa dari sifat kikir dan pelit sekaligus merupakan benteng pengamanan dalam ekonomi Islam yang dapat menjamin kelanjutan dan kestabilannya. 


\section{Tabel 1}

Pengetahuan Responden tentang Keberadaan Lembaga Amil Zakat BAZNAS Kabupaten Pasaman Barat

\begin{tabular}{cccc}
\hline Lembaga Amil Zakat & Tahu & Tidak Tahu & Total \\
\hline $\begin{array}{c}\text { BAZNAS Kab. } \\
\text { Pasaman barat }\end{array}$ & 55 & 45 & 100 \\
\hline $\begin{array}{c}\text { UPZ Kecamatan } \\
\text { Gunung Tuleh }\end{array}$ & 60 & 40 & 100 \\
\hline $\begin{array}{c}\text { Panitia Pengumpul Zakat } \\
\text { yang dibentuk masyarakat }\end{array}$ & 100 & - & 100 \\
\hline
\end{tabular}

Data pada Tabel 1 menjelaskan bahwa dari 100 orang responden Kecamatan Gunung Tuleh Kabupaten Pasaman Barat, diketahui bahwa pengetahuan masyarakat (muzakki) terhadap adanya Lembaga Amil Zakat BAZNAS Kabupaten Pasaman Barat, terlihat pada tabel 1 dimana masyarakat memiliki masing-masing jawaban terhadap adanya Lembaga Amil Zakat BAZNAS diatas 50\%. Ini menunjukkan bahwa BAZNAS Kabupaten Pasaman Barat cukup dikenal dengan baik di kalangan masyarakat Kecamatan Gunung Tuleh Kabupaten Pasaman Barat. Lembaga Amil Zakat yang paling diketahui masyarakat yaitu Panitia Pengumpul Zakat yang dibentuk masyarakat sebesar 100\%. Kemudian diikuti Unit Pengumpul Zakat/UPZ Kecamatan Gunung Tuleh sebanyak 60 orang yang tahu akan keberadaan UPZ Kecamatan Gunung Tuleh dan 40 orang yang tidak mengetahui adanya UPZ Kecamatan Gunung Tuleh dan BAZNAS Kabupaten Pasaman Barat sebanyak 55 orang yang tahu akan keberadaan BAZNAS Kota dan terdapat 45 orang yang tidak mengetahui.

\section{B. Alasan Masyarakat Tidak Membayar Zakat di BAZNAS Kabupaten Pasaman} Barat

Secara umum alasan masyarakat tidak membayar zakat di BAZNAS Kabupaten Pasaman Barat yaitu dapat dilihat dari Tabel 2.

\section{Tabel 2}

JISFIM: Journal of Islamic Social Finance Management, Volume 2, No 1 Tahun 2020 http://jurnal.iain-padangsidimpuan.ac.id/index.php/JISFIM 


\section{Penyebab Responden Tidak Membayar Zakat melalui BAZNAS \\ Kabupaten Pasaman Barat}

\begin{tabular}{lcc}
\hline Alasan Masyarakat Tidak Membayar Zakat di & Frekuensi & $\begin{array}{c}\text { Persentase } \\
\text { (\%) }\end{array}$ \\
Kabupaten Pasaman Barat & 40 & 40 \\
\hline $\begin{array}{l}\text { Religiusitas (Masyarakat merasa lebih afdhal } \\
\text { memberikan zakat langsung kepada mustahiq yang } \\
\text { masih merupakan saudara, keluarga dekat ataupun } \\
\text { tetangga yang lebih membutuhkan) }\end{array}$ & 19 & 19 \\
\hline $\begin{array}{l}\text { Pelayanan (Pelayanan BAZNAS Kabupaten Pasaman } \\
\text { Barat yang diberikan masih belum memuaskan } \\
\text { masyarakat) }\end{array}$ & 19 \\
$\begin{array}{l}\text { Lokasi (Lokasi/jarak BAZNAS Kabupaten Pasaman } \\
\text { Barat yang cukup jauh dari tempat tinggal masyarakat) }\end{array}$ & 21 & 21 \\
\hline $\begin{array}{l}\text { Kepercayaan (Kurangnya kepercayaan masyarakat } \\
\text { terhadap BAZNAS Kabupaten Pasaman Barat dalam } \\
\text { menyalurkan zakat kepada mustahiq dan kurangnya } \\
\text { informasi yaitu manajemen dana zakat dikelola secara } \\
\text { terbuka atau transparan) }\end{array}$ & 20 & 20 \\
\hline Total & 100 & 100 \\
\hline
\end{tabular}

Pada tabel 2 menjelaskan bahwa dari 100 orang masyarakat Kecamatan Gunung Tuleh Kabupaten Pasaman Barat yang bersedia menjadi responden terdapat beberapa alasan masyarakat tidak membayar zakat di BAZNAS Kabupaten Pasaman Barat yaitu Religiusitas, Pelayanan, Lokasi dan Kepercayaan.

1. Religiusitas (Keagamaan)

Religiusitas merupakan alasan yang paling besar dipilih oleh masyarakat Kecamatan Gunung Tuleh Kabupaten Pasaman Barat yang menjadi responden yaitu sebanyak 40 orang (40\%), karena masyarakat merasa lebih afdhal memberikan zakat langsung kepada yang masih merupakan saudara, keluarga dekat atau kerabat yang lebih membutuhkan.

2. Lokasi

Lokasi merupakan jarak atau tempat BAZNAS Kabupaten Pasaman Barat yang menjadi alasan masyarakat yaitu sebesar 19 orang (19\%), karena masyarakat atau muzakki tidak tahu atau kurang mengetahui letak kantor BAZNAS Kabupaten Pasaman Barat sehingga masyarakat tidak mau membayar zakat di BAZNAS Kabupaten Pasaman Barat. 
3. Pelayanan

Pelayanan menjadi alasan yang juga banyak dipilih oleh masyarakat Kecamatan Gunung Tuleh Kabupaten Pasaman Barat yang menjadi responden yaitu sebanyak 21 orang (21\%), karena masyarakat masih belum merasakan pelayanan yang bagus salah satunya menjemput langsung zakat muzakki ke rumah warga dan ketepatan waktu yang diberikan oleh pihak BAZNAS itu sendiri.

4. Kepercayaan

Kepercayaan juga menjadi salah satu alasan masyarakat tidak membayar zakat melalui Lembaga Amil Zakat yaitu dapat dilihat dari hasil responden yaitu sebanyak 20 orang (20\%), karena masyarakat masih kurang percaya dan kurang yakin akan tanggung jawab sebuah lembaga amil Zakat BAZNAS tersebut, padahal lembaga tersebut telah dipilih dan ditetapkan langsung oleh pemerintah.

\section{Usaha yang dilakukan BAZNAS Kabupaten Pasaman Barat dalam Mengatasi Masyarakat yang tidak Membayar Zakat melalui BAZNAS Kabupaten Pasaman Barat.}

Zakat bukan hanya sekedar ibadah yang wajib bagi orang muslim, akan tetapi zakat juga sudah menjadi kebijakan negara yang di terapkan dengan sebuah strategi agar mampu menjadi sumber pendapatan negara untuk memberikan kesejahteraan kepada masyarakat. Hal tersebut menjadi penjelasan akan arti subtansi pokok pelaksanaan kewajiban zakat tersebut yaitu untuk menjadi solusi terwujud kesejahteraan ekonomi bagi kehidupan umat muslim.

Bertolak dari pandangan tersebut, maka pada permasalahan zakat di Kecamatan Gunung Tuleh Kabupaten Pasaman Barat yang menjadi alasan masyarakat tidak membayar zakat melalui lembaga yang ada maka dapat dinyatakan bahwa sangat perlu dirumuskannya suatu strategi yang tepat terhadapat pelaksanaan zakat agar lebih terberdayakan, baik pada sisi pengumpulan maupun pada sisi pengelolaan dan penyalurannya agar benar-benar dapat menjadi solusi untuk mengatasi permasalahan tersebut. Sebanyak 90\% mayoritas masyarakat menganut agama Islam namun dalam catatan dokumentasi dari BAZNAS Provinsi Jambi pada Bulan Desember 2020 lalu, masyarakat yang menyalurkan Zakat melalui BAZNAS sebanyak \pm (6o Jiwa) saja.

Oleh sebab itu di perkirakan hanya $\pm 30 \%$ jiwa yang beragama muslim yang menyalurkan zakat melalui Lembaga Amil Zakat di BAZNAS Kabupaten Pasaman Barat. Maka dari hasil data tersebut dapat diketahui bahwa masih banyak masyarakat yang belum menyadari dan belum tau akan keharusan mereka untuk menyalurkan zakat 
melalui Lembaga Amil Zakat di BAZNAS Kabupaten Pasaman Barat yang telah di tetapkan oleh pemerintah melalui UU No. 23 Tahun 2011. Oleh sebab itu langkah yang perlu dilakukan BAZNAS dalam mengatasi masyarakat yang tidak membayar atau menyalurkan zakat melalui Lembaga Amil Zakat yaitu:

Menurut Bapak Suharman sebagai salah satu pengurus BAZNAS mengatakan bahwa: "Dengan adanya penyebab masyarakat yang masih banyak tidak membayar zakat melalui BAZNAS maka langkah yang kami lakukan saat ini yaitu dengan melakukan dakwah tentang pentingnya penyaluran zakat melalui Lembaga Amil zakat BAZNAS Kabupaten Pasaman Barat, melakukan penyuluhan kepada masyarakat, melakukan sosialisasi langsung kepada masyarakat untuk lebih memperhatikan akan manfaat dan tujuan dari penyaluran zakat, meyakinkan masyarakat akan tanggung jawab Lembaga amil Zakat BAZNAS Kabupaten Pasaman Barat dalam penanganan dana zakat yang langsung akan diberikan kepada para golongan mustahiq yang lebih membutuhkan".

Dari uraian wawancara di atas maka langkah yang dapat dilakukan oleh pihak BAZNAS dalam menangani masyarakat yang tidak membayar zakat melalui lembaga amil zakat dapat berjalan dengan semestinya dan lebih terorganisir, agar masyarakat lebih tahu akan manfaat, tujuan, fungsi dan kepercayaan dalam menyalurkan zakat melalui Lembaga Amil Zakat di BAZNAS Kabupaten Pasaman Barat.

Beberapa kegiatan pembinaan yang dapat dilakukan melalui instrument-instrumen yang ada di masyarakat sebagai langkah upaya pemberdayaan zakat tersebut antara lain adalah :

1. Dari sebuah Lembaga Amil Zakat tersebut untuk lebih aktif dalam melakukan kegiatan sosialisasi tentang zakat kepada masyarakat agar masyarakat lebih mengetahui fungsi dan manfaat dari sebuah Lembaga Amil Zakat dalam penyaluran dana zakat . Lembaga Amil Zakat Juga perlu untuk lebih meyakinkan masyarakat agar lebih mengerti dan paham akan keharusan dalam penyaluran zakat melalui Lembaga Amil Zakat (BAZNAS) yang telah di sahkan oleh Pemerintah melalui Undang-Undang yang nantinya hasil dari dana zakat tersebut akan di salurkan langsung kepada delapan asnab yang berhak menerima zakat tersebut.

2. Pembinaan melalui instrument kelembagaan da'wah

a. Pembinaan melalui kelembagaan Majelis Ta’lim

Dalam rangka membagun pemahaman yang komprehensif terhadap ibadah zakat salah satu kelembagaan keagamaan yang dapat menjadi sarana JISFIM: Journal of Islamic Social Finance Management, Volume 2, No 1 Tahun 2021 http://jurnal.iain-padangsidimpuan.ac.id/index.php/JISFIM 
pembinaan adalah Majelis Ta'lim melalui wadah ini untuk memberikan pemahaman kepada masyarakat yang dapat mewujudkan kesadaran berzakat bagi mereka yang memiliki kemampuan harta.

Dalam konteks ini pula sosialisasi tentang Undang-Undang yang mengatur tentang pelaksanaan zakat perlu dilakukan, sebagai konsekuensi logis degan lahirnya Undang-Undang yang mengatur tentang pelaksanaan zakat dengan muatan instrumen, tujuan, fungsi, dan harapan dari zakat itu sendiri, menjadi wajib dipahami oleh semua pihak termasuk warga masyarakat umumnya pada masyarakat Kecamatan Gunung Tuleh Kabupaten Pasaman Barat di dominasi oleh warga muslim.

Sosialisasi pelaksanaan Undang-Undang Nomor 23 Tahun 2011 tentang pelaksanaan zakat menjadi penting sebagai salah satu strategi awal dan mendasar agar pemahaman masyarakat terhadap Undang-undang itu sendiri, serta tujuan dan fungsi zakat berdasarkan kajian dan pemahaman agama mampu terwujud.

Harapan tersebut tentu tidak mudah, pasti membutuhkan kerja keras oleh semua pihak terkait, khususnya Lembaga Amil Zakat BAZNAS sebagai lembaga resmi yang terbentuk berdasarkan Undang-Undang tersebut, berkewajiban mensosialisasikannya dengan memanfaatkan berbagai momentum kegiatan, salah satunya adalah melalui madah majelis ta'lim.

Hasil sosialisasi tersebut diharapkan mampu membangun motivasi terhadap pelaksaan zakat yang dapat menciptakan terlaksananya programprogram terkait masalah kemiskinan.

b. Pembinaan Melalui Tema-tema Khutbah Jumat dan Ceramah Amaliah Ramadhan.

Salah satu instrumen yang juga memiliki peran yang sangat strategis dalam memberikan pembinaan terhadap pemahaman tata pelaksanaan zakat dengan mengangkat tema-tema yang berkaitan dengan subtansi zakat baik pada kegiatan khutbah jumat maupun pada ceramah-ceramah dalam amaliah ramadhan.

Hal ini penting karena bulan Ramadhan dimaknai oleh masyarakat sebagai masa yang memiliki momentum yang tepat untuk menyalurkan zakat dengan pertimbangan besarnya pahala bagi mereka yang memanfaatkan bulan Ramadhan sebagai momentum ibadah. Berdasarkan beberapa hasil wawancara 
dengan warga masyarakat yang tergolong tingkat ekonomi menengah keatas, menunjukkan bahwa tumbuh kesadaran dan motivasi untuk melaksanakan zakat dengan penuh tanggung jawab setelah mendengarkan tema-tema ceramah agama maupun khutbah jumat yang merasionalkan manfaat pelaksanaan zakat, dengan contoh-contoh konkrit dalam kehidupan sehari-hari diantaranya sebagai berikut:

Wawancara dengan Bapak Andi yang mempunyai toko pupuk dan bahan pestisida warga Kecamatan Gunung Tuleh ia mengatakan bahwa: Ada seorang ustad yang ceramah di Masjid Raya Al-Manar Paraman Ampalu waktu sholat jum'at dua bulan yang lalu menjelaskan dan memberi himbauan kepada masyarakat yang memiliki harta, maka hitunglah zakatmu dengan benar karena itu tanggung jawab kita kepada lalu pilihlah antara mereka yang membutuhkan bantuan lalu bersilaturrahim kepada mereka, lalu bimbing agar mereka mampu menekuni usaha produktif dari modal pemberian zakat anda dengan jumlah yang memadai. Selanjutnya beri motivasi dengan mengatakan tahun ini anda yang menerima zakat untuk membangun usaha produktif berjanjilah agar usaha ini sukses tahun depan anda juga termasuk yang memberi zakat bukan lagi penerima zakat maka itu juga menjadi dorongan bagi kami mengerti akan pentingnya berzakat.

Berdasarkan hasil wawancara yang telah dikemukakan, bahwa tema-tema dakwah zakat yang disampaikan melalui mimbar sholat jum'at dan mimbar amaliah Ramadhan sangat efektif mengedukasi dan memotivasi masyarakat apalagi jika penyampaiannya yang sangat rasional dengan pemahaman yang dimiliki.

\section{Pembinaan Muzakki dan Mustahik}

Salah satu tujuan zakat adalah meningkatkan derajat fakir miskin dan taraf hidupnya serta sarana pemerataan pendapatan secara sosial. Sehingga penerimaan manfat zakat dapat memperbaiki kesejahteraan dan taraf hidup taraf hidup para mustahik.

Pembinaan kepada muzakki untuk menjelaskan fungsi dan tujuan zakat, salah satunya adalah untuk membantu ketahanan ekonomi bagi keluarga miskin, untuk itu informasi pencerahan diberikan bahwa muzakki dapat melaksanakan penyaluran zakat secara mandiri dengan satu syarat bahwa pemberian zakat kepada mustahik harus dengan perinsif skala proritas, memiliki azas maanfaat sebagai usaha produktif tentu dengan jumlah yang memadai dan tidak dieksploitasi melalui media demi untuk menjaga perasaan para mustahiq.

Inventarisasi peta potensi dan besaran jumlah zakat yang dimiliki muzakki, demikian juga besaran masyarakat miskin yang perlu mendapat bantuan dan pembinaan ekonomi menjadi sangat penting untuk memudahkan menyusun JISFIM: Journal of Islamic Social Finance Management, Volume 2, No 1 Tahun 2021 http://jurnal.iain-padangsidimpuan.ac.id/index.php/JISFIM 
pemetaan sasaran yang harus ditindak lanjuti sebagai penyaluran zakat yang efektif.

Disinilah letak pentingnya inventarisasi potensi muzakki dan inventarisasi harapan mustahiq. Hal ini dapat terlaksana apabila terbangun kerja sama yang baik antara semua pihak yang terkait, antara lain masyarakat itu sendiri, Lembaga Amil Zakat yang diwakili oleh UPZ-UPZ di setiap Kecamatan, aparat desa, tokoh masyarakat (seperti ketua RT), para alim ulama, dan tidak terkecuali adalah para penyuluh agama Islam, muballig dan Juru Dakwah yang ada di masyarakat.

Bahkan disinyalir bila penyuluh agama Islam sebagai petugas fungsional yang diangkat oleh pemerintah sukses pengembang tugasnya sebagai penyuluh di masyarakat yang bekerja sama dengan semua pihak terkait dengan UPZ-UPZ yang ada di Kecamatan, maka dapat dipastikan akan menjadi mudah menginventarisir potensi zakat secara maksimal yang ada di Kecamatan Gunung Tuleh Dalam waktu yang bersamaan dapat pula menginventarisir harapan dan keinginan warga masyarakat yang tergolong sebagai mustahiq. Maka program pengentasan kemiskinan melalui zakat dapat dilaksanakan secara berkesinambungan, terprogram, berdasarkan skala prioritas kebutuhan yang ada di masyarakat. Akan dapat dipastikan dalam waktu yang tidak begitu lama upaya penigkatan tarap hidup keluarga meskin dapat tercapai.

Maka dari semua uraian tentang pertanyaan di atas dapat di kemukakan bahwa, dari persepsi masyarakat dalam membayar zakat di BAZNAS Kabupaten Pasaman Barat yaitu bahwa masyarakat masih banyak yang kurang tahu dan paham akan pentingnya fungsi zakat, dan penyaluran zakat melalui Lembaga Amil Zakat di BAZNAS Kabupaten Pasaman Barat, namun ada yang tahu dan paham akan keharusan dalam membayar zakat melalui Lembaga Amil Zakat tetapi masih tidak mau menyalurkan zakat melalui Lembaga Amil Zakat yang telah ditetapkan oleh pemerintah tersebut. Bagi masyarakat yang penting mereka telah menjalankan perintah untuk menjalankan kewajiban sebagai seorang umat muslim dalam berzakat.

Adapun alasan masyarakat tidak membayar zakat melalui Lembaga Amil Zakat (BAZNAS Kabupaten Pasaman Barat) yaitu salah satunya karena masyarakat masih kurang percaya dan kurang yakin akan tanggung jawab dari sebuah lembaga tersebut dalam menangani pengelolaan zakat, dan juga dari hasil wawancara bersama salah seorang warga sebagai wiraswasta (pedagang pupuk dan bahan pestisida) yang telah wajib mengeluarkan zakatnya jika telah mencapai nisabnya, bahwa ia beranggapan jika memberi zakat langsung kepada orangnya yang 
membutuhkan lebih afdhol di banding ke sebuah lembaga.

Adapun langkah-langkah dan kebijakan yang perlu dilakukan dalam mengatasi masyarakat tidak membayar zakat melalui Lembaga Amil Zakat yaitu, dari sebuah Lembaga Amil Zakat itu sendiri untuk lebih aktif dalam melakukan sosialisasi atau penyuluhan tentang zakat kepada masyarakat agar masyarakat lebih tahu dan mengerti akan keharusan dan keuntungan dalam membayar zakat melalui Lembaga Amil Zakat di BAZNAS Kabupaten Pasaman Barat.

\section{KESIMPULAN}

Berdasarkan hasil penelitian yang didapatkan, dapat ditarik kesimpulan bahwa masyarakat masih banyak yang kurang tahu dan paham akan pentingnya fungsi zakat, manfaat dan tujuan pembayaran atau penyaluran zakat melalui Lembaga Amil Zakat di BAZNAS Kabupaten Pasaman Barat, namun ada juga yang tahu dan paham akan keharusan dalam membayar zakat melalui Lembaga Amil Zakat namun masyarakat tidak mau membayar atau menyalurkan zakat melalui Lembaga Amil Zakat yang telah ditetapkan oleh pemerintah tersebut, dengan alasan bagi mereka yang penting telah menjalankan perintah untuk menjalankan kewajiban sebagai seorang umat muslim dalam berzakat. Kemudian, masyarakat beranggapan jika memberi zakat langsung kepada orang yang membutuhkan lebih afdhal di banding ke BAZNAS. Adapun kebijakan yang harus dilaksanakan oleh BAZNAS Kabupaten Pasaman Barat dalam agar masyarakat mau membayar zakat melalui Lembaga Amil Zakat yaitu, dari sebuah Lembaga Amil Zakat itu sendiri untuk lebih aktif dalam melakukan sosialisasi atau penyuluhan tentang zakat kepada masyarakat agar masyarakat lebih tahu dan mengerti akan keharusan dan keuntungan dalam membayar atau menyalurkan zakat melalui Lembaga Amil Zakat Di BAZNAS Kabupaten Pasman Barat.

\section{DAFTAR PUSTAKA}

Abdullah, Junaidi. (2018). Institusi Pengelola Zakat Dalam Hukum Positif Di Indonesia. ZISWAF: Jurnal Zakat dan Wakaf. https://scholar.google.com

Atabik, Ahmad. (2015). Peranan Zakat Dalam Pengentasan Kemiskinan. ZISWAF: Jurnal Zakat dan Wakaf. https://scholar.google.com

Anwar, Ahmad Thoharul. (2018). Zakat Produktif Untuk Pemberdayaan Ekonomi Umat. ZISWAF: Jurnal Zakat dan Wakaf. https://scholar.google.com

Gunawan, Karebet. (2017). Pelayanan Lembaga Zakat Untuk Meningkatkan Kepuasan Muzakki. ZISWAF: Jurnal Zakat dan Wakaf. https://scholar.google.com

Hafhiduddin, Didin. (2002). Zakat dalam Perekonomian Modern. Gema Insani Press. JISFIM: Journal of Islamic Social Finance Management, Volume 2, No 1 Tahun 2021 http://jurnal.iain-padangsidimpuan.ac.id/index.php/JISFIM 
Hisamuddin, Nur. (2014). Persepsi, Penyajian Dan Pengungkapan Dana Non Halal Pada BAZNAS Dan PKPU Kabupaten Lumajang. ZISWAF: Jurnal Zakat dan Wakaf. https://scholar.google.com

Listyana, Rohmaul \& Hartono, Yudi. (2015). Persepsi Dan Sikap Masyarakat Terhadap Penanggalan Jawa Dalam Penentuan Waktu Pernikahan (Studi Kasus Desa Jonggrang Kecamatan Barat Kabupaten Magetan Tahun 2013). Jurnal Agastya. https://core.ac.uk/download/pdf/229500722

Nafi, Muhammad Agus Yusrun. (2020). Analisa Efektivitas Penyaluran Zakat Baznas Kabupaten Kudus. ZISWAF: Jurnal Zakat dan Wakaf. https://scholar.google.com

Nofiaturrahmah, Fifi .2015. Pengumpulan Dan Pendayagunaan Zakat Infak Dan Sedekah. ZISWAF: Jurnal Zakat dan Wakaf. https://scholar.google.com

Nuruddin, M. (2014). Transformasi Hadis-Hadis Zakat Dalam Mewujudkan Ketangguhan Ekonomi Pada Era Modern. ZISWAF: Jurnal Zakat dan Wakaf. https://scholar.google.com

Riyadi, Fuad. 2015. Kontroversi Zakat Profesi Pesrpektif Ulama Kontemporer. ZISWAF: Jurnal Zakat dan Wakaf. https://scholar.google.com

Sarwono, Sarlito W . (2010). Pengantar Psikologi Umum. Rajawali Pers.

Syafiq, Ahmad. 2014. Prospek Zakat Dalam Perekonomian Modern. ZISWAF: Jurnal Zakat dan Wakaf. https://scholar.google.com

Syafiq, Ahmad. (2016). Urgensi Peningkatan Akuntabilitas Lembaga Pengelola Zakat. ZISWAF: Jurnal Zakat dan Wakaf. https://scholar.google.com

Undang-Undang Nomor 23 Tahun 2011 tentang Pengelolaan Zakat

PP no. 14 tahun 2014 tentang Pelaksanaan UU no. 23 Tahun 2011 tentang Pengelolaan Zakat

Qardhawi, Yusuf. (1987). Hukum Zakat. Pustaka Lentera Antar Nusa. 